\title{
Apomorphine in treatment of Parkinson's disease: comparison between subcutaneous and sublingual routes
}

\author{
D Deffond, F Durif, $M$ Tournilhac
}

\begin{abstract}
The efficacy of two routes of apomorphine, subcutaneous (SC) and sublingual (SL), successively administered in 7 Parkinsonian patients with motor fluctuations, was compared in reducing the daily duration of "off" phases. The mean duration of SC and SL treatment was $7 \cdot 7$ and 6.8 months respectively. The mean time spent in "off" phase was $55 \%$ after SC and $68 \%$ after SL treatment. The mean time before turning "on" after an "off" period was 14 minutes after SC and 28 minutes after SL treatment. Two patients developed stomatitis after SL route. SL apomorphine may be helpful in the treatment of motor fluctuations in PD.
\end{abstract}

(F Neurol Neurosurg Psychiatry 1993;56:101-103)

Apomorphine, a very potent mixed dopaminergic agonist ${ }^{1}$ when given subcutaneously is an effective agent in the treatment of "off" phases in Parkinsonian patients with motor fluctuations. ${ }^{2-5}$ However, the methods of administration currently used ("penject" or minipump), are expensive, technically complex, difficult to carry out by severely akinetic patients and responsible for local side effects at the site of injection. ${ }^{4}$

Some authors have recently reported that acute administration of sublingual (SL) apomorphine alleviates Parkinsonian symptoms, with as large and prolonged an effect as subcutaneous (SC) treatment. ${ }^{6-9}$

As sublingual administration might be more practicable in the patient population concerned, we compared the effectiveness of subcutaneous and sublingual apomorphine in reducing the daily duration of "off" phases in chronic administration.

\footnotetext{
Clinique

Neurologique, Hôpital

Fontmaure, avenue de

Villars, 63400,

Chamalieres, France

D Deffond

F Durif

M Tournilhac

Correspondence to:

Dr Durif

Received 5 March 1992.

Accepted 24 April 1992
}

\section{Patients and methods}

Seven patients with Parkinson's disease (PD), 5 men and 2 women, were included in the study after they gave informed consent and the trial was approved by the local ethical committee. All had disabling "on-off” fluctuations in motor performance despite optimal adjustment of levodopa regimen and use of dopamine agonists. The mean (SD) dose of levodopa and bromocriptine was respectively
843 (387) $\mathrm{mg}$ and [39 (22) $\mathrm{mg}, 5$ patients]. Their mean age was 60 (7), their mean (SD) duration of disease $13.5(4 \cdot 5)$ and of levodopa therapy $12.4(5.4)$ years. No patient with significant cardiovascular, renal, hepatic or neuropsychiatric disorders was included.

All patients were admitted to hospital for assessment of motor fluctuations for at least 4 days before the beginning of the trial. Patients were given a diary in which they recorded the duration of "off" periods and the severity of "off" phases and abnormal involuntary movements on a 4 point scale. ${ }^{5}$ The motor score, in "on" and "off" phases, was scored using the Unified Parkinson's Disease Rating Scale. ${ }^{10}$ The study was divided into two parts. In the first part, all patients were treated with intermittent subcutaneous injection of apomorphine (using a "D-pen", Disetronic Switzerland). In the second part, after the treatment with subcutaneous injection was stopped, apomorphine was administered sublingually (40 mg secable tablets, Chabre Laboratory, France). For each route, apomorphine was given during an off period, and the dose was progressively increased until the optimal effective dose in each patient was obtained. They were then instructed to use apomorphine as soon as patients observed an "off" phase and on how to use the D-pen and sublingual tablets.

To avoid apomorphine peripheral side effects domperidone ( $20 \mathrm{mg}$, three times daily) was started 72 hours before the first apomorphine administration and continued until the end of the study.

For each route, the same evaluation of motor fluctuations, as described above, was performed at least after one month of treatment and was repeated at monthly intervals. During each period of evaluation, patients noted the number of apomorphine administration per day, and the necessary time before turning "on" after an "off" phase.

Routine blood laboratory tests were performed before apomorphine therapy, then weekly for a month and afterwards monthly.

Results are expressed as mean (SD) and statistical analysis was performed with the Wilcoxon's test.

\section{Results}

Before apomorphine administration, a mean 40 (28) \% of the day was spent in the "off" 
Table 1 Comparison of clinical and pharmacological parameters after subcutaneous and sublingual routes of apomorphine

\begin{tabular}{|c|c|c|c|c|c|c|c|c|c|c|c|c|}
\hline \multirow[b]{2}{*}{ Patient } & \multirow[b]{2}{*}{$\begin{array}{l}\text { Weight } \\
(\mathrm{kg})\end{array}$} & \multirow[b]{2}{*}{$\begin{array}{l}\text { Off } \\
\text { hours (\%) } \\
\text { before } \\
\text { apomorphine }\end{array}$} & \multicolumn{5}{|c|}{ Subcutaneous apomorphine $(n=7)$} & \multicolumn{5}{|c|}{ Sublingual apomorphine $(n=7)$} \\
\hline & & & $\begin{array}{l}\text { Off } \\
\text { hours } \\
(\%)\end{array}$ & $\begin{array}{l}\text { Apomorphine } \\
\text { dose (mg) }\end{array}$ & $\begin{array}{l}\text { Number } \\
\text { of dose } \\
\text { per day }\end{array}$ & $\begin{array}{l}\text { Delay of } \\
\text { action } \\
\text { (min) }\end{array}$ & $\begin{array}{l}\text { Duration } \\
\text { of } \\
\text { treatment } \\
\text { (months) }\end{array}$ & $\begin{array}{l}\text { Off } \\
\text { hours } \\
(\%)\end{array}$ & $\begin{array}{l}\text { Apomorphine } \\
\text { dose (mg) }\end{array}$ & $\begin{array}{l}\text { Number } \\
\text { of dose } \\
\text { per day }\end{array}$ & $\begin{array}{l}\text { Delay of } \\
\text { action } \\
\text { (min) }\end{array}$ & $\begin{array}{l}\text { Duration } \\
\text { of } \\
\text { treatment } \\
\text { (months) }\end{array}$ \\
\hline $\begin{array}{l}1 \\
2 \\
3 \\
4 \\
5 \\
6 \\
7\end{array}$ & $\begin{array}{l}70 \\
88 \\
33 \\
85 \\
52 \\
77 \\
69\end{array}$ & $\begin{array}{r}39 \\
37 \\
26 \\
100 \\
18 \\
39 \\
21\end{array}$ & $\begin{array}{r}24 \\
10 \\
13 \\
39 \\
11 \\
28 \\
5\end{array}$ & $\begin{array}{l}4 \\
5 \\
2 \\
4 \\
7 \\
4 \\
3\end{array}$ & $\begin{array}{l}3.5 \\
5.3 \\
2.3 \\
4 \cdot 6 \\
3.0 \\
2.8 \\
1.5\end{array}$ & $\begin{array}{r}10 \\
15 \\
20 \\
15 \\
5 \\
12 \\
20\end{array}$ & $\begin{array}{r}11 \\
6 \\
6 \\
15 \\
5 \\
7 \\
4\end{array}$ & $\begin{array}{r}5 \\
10 \\
14 \\
14 \\
16 \\
16 \\
18\end{array}$ & $\begin{array}{l}20 \\
60 \\
40 \\
60 \\
40 \\
40 \\
40\end{array}$ & $\begin{array}{l}4 \cdot 0 \\
2 \cdot 6 \\
2 \cdot 4 \\
3 \cdot 0 \\
1 \cdot 5 \\
3 \cdot 2 \\
1 \cdot 5\end{array}$ & $\begin{array}{l}30 \\
45 \\
20 \\
35 \\
17 \\
20 \\
30\end{array}$ & $\begin{array}{r}12 \\
8 \\
3 \\
9 \\
9 \\
2 \\
5\end{array}$ \\
\hline
\end{tabular}

phase. All patients showed a striking improvement with apomorphine treatment, as the percentage of diurnal time spent in "off" phase fell to $18(12) \%$ (mean reduction : $55 \%, \mathrm{p}<$ 0.02 ) with SC administration [mean duration of treatment : $7 \cdot 7(3.9)$ months] and to 13 (4) $\%$ (mean reduction : $68 \%, \mathrm{p}<0.02$ ) with $\mathrm{SL}$ administration [mean duration of treatment:6.8 (3.6) months].

The mean dose per administration was $4 \cdot 1$ (1.5) $\mathrm{mg}[61(21) \mu \mathrm{g} / \mathrm{kg}]$ by SC route and 42.8 $(13.8) \mathrm{mg}[638(209) \mu \mathrm{g} / \mathrm{kg}]$ by SL route. The mean frequency of administration was respectively $3.2(1.3)$ and $2.6(0.3)$ per day. Onset of clinical effect began after $14(5) \mathrm{min}$ with SC apomorphine and after 28 (20) min with SL apomorphine (table).

No significant aggravation of AIM or improvement in severity of "off" phases occurred either with SC nor with SL route. Reduction of dosage of levodopa and dopamine agonists were not statistically significant.

After SC injection, patients developed some painless nodules in the abdominal wall. All patients noted a bitter taste after SL administration. Two patients developed stomatitis with burning tongue and stopped SL administration after 2 and 3 months, respectively. These local adverse effects disappeared in a week. No biological side effect was observed.

\section{Discussion}

After SC administration, our results agree with previous reports. ${ }^{2-5}$ We found that during a mean seven month period of treatment, the SL route was of similar efficacy to the SC route, with a mean reduction of "off" hours of about $68 \%$. No tolerance was observed. Other authors had recently reported clinical benefit with SL apomorphine in treating motor fluctuations. Their results, with a mean reduction of daily "off” hours of about $55 \%$, were slightly less impressive than ours, but they did not use as high doses as we did. ${ }^{712}$

The major problem of the SL route was found to be the delayed action when compared to the SC route (28 minutes vs 14 minutes), limiting its use for severely akinetic patients. This latency of the onset of motor benefit might be explained by the time needed for the dissolution of the tablet (mean 27 minutes from report of patients) and could be decreased by using a new excipient with a more rapid dissolution time. At the end of the study,
2 patients had preferred the association of the two routes by using SC injection in the treatment of severe early morning akinesia and SL administration in the other daily "off" periods.

Despite a delayed action, SL apomorphine was found to be more efficient than SC apomorphine (mean reduction of "off" hours: SC : $55 \%$; SL : $68 \%$ ). In acute studies, the duration of the effect after SL administration was longer than after SC injection. ${ }^{6-10}$ Moreover, for most of the patients, SL tablets were more convenient and avoided the need for help, which was not always the case with SC injections. ${ }^{4}$ Finally, this non-traumatic method is often easily accepted by some patients who are afraid of self SC injection.

The effective SL dose $(630 \mu \mathrm{g} / \mathrm{kg})$ was about ten-fold higher than the effective SC dose (61 $\mu \mathrm{g} / \mathrm{kg}$ ), which was of the same magnitude previously reported. These results were in agreement with the study of Montastruc et al, ${ }^{12}$ which showed a bioequivalence between $30 \mathrm{mg}$ of SL and $3 \mathrm{mg}$ of SC treatment. This poor bioavailability could be partially explained by the time needed for the dissolution of the tablet probably leading to the swallowing of a part of the administered dose.

Despite a mean daily dosage of SL apomorphine of $151 \mathrm{mg}$, no case of uraemia was recorded. Such a side effect had been recorded by Cotzias et $a l^{13}$ after higher doses ( 400 to $1600 \mathrm{mg}$ ) administered orally, and was probably due to liver production of nephrotoxic catabolites. ${ }^{7}$ This is avoided by SL administration since lingual mucosa is drained by systemic circulation and not by the portal vein. The limitation of this treatment was the development of stomatitis in 2 of 7 patients after 2 months of treatment, a side effect already reported by Montastruc et al, ${ }^{12}$ in 4 of 8 patients. These local side effects may be allied to the subcutaneous nodules and vestibulitis observed respectively after SC injection ${ }^{5}$ and intranasal administration. ${ }^{14}$ The pathophysiology of this drug-effect is unknown.

SL apomorphine could be interesting for the treatment of severe motor fluctuations in PD. However, it seems necessary to develop a new excipient to decrease the local side effects and the latency of the onset of motor benefit.

1 Lal S. Apomorphine in the evaluation of dopaminergic function in man. Prog Neuro Psychopharmacol Biol Psychiat 1988;12:117-64 
2 Frankel JP, Lees AJ, Kempster PA, Stern GM. Subcutaneous apomorphine in the treatment of Parkinson's disease f Neurol Neurosurg Psychiatry 1990;53:96-101.

3 Poewe W, Kleedorfer B, Gerstenbrand F, Oertel W. Subcutaneous apomorphine in Parkinson's disease. Lancet 1988;i:943.

4 Pollak P. Champay AS, Gaio JM, Hommel M, Benabid AL, Perret J. Administration sous-cutanée d'apomorphine dans les fluctuations motrices de la maladie de Parkinson. Rev Neurol 1990;146:116-22.

5 Stibe CMH, Kempster PA, Lees AJ, Stern GM. Subcutaneous apomorphine in parkinsonian on-off fluctuations. Lancet 1988;i:403-6.

6 Durif F, Deffond D, Tournilhac M. Efficacy of sublingual apomorphine in Parkinson's disease. $f$ Neurol Neurosurg

7 Gancher ST, Nutt JG, Woodward WR. Absorption of apomorphine by various routes in parkinsonism. Mov Dis 1991;6:212-6.

8 Lees AJ, Montastruc JL, Turjanski N, Rascol O, Kleedorfer B, Saint Paul H, Stern GM, Rascol A. Sublingual apomorphine and Parkinson's disease. $\mathcal{F}$ Neurol Neurosurg Psychiatry 1989;52:1440

9 Hughes AJ, Webster R, Bovington M, Lees AJ, Stern GM.
Sublingual apomorphine in the treatment of Parkinson's disease complicated by motor fluctuations. Clin Neuropharmacol 1991;14:556-61.

10 Fahn S, Elton RLL and members of the UPDRS committee. Unified Parkinson's Disease Rating Scale. In: Fahn S, Marsden CD, Goldstein M, Calne DB, eds. Recent developments in Parkinson's disease. New York: Macmillan, 1987:153-63 and appendices I, II.

11 Durif F, Jeanneau E, Serre-Debeauvais F, Deffond D, Eschalier A, Tournilhac M. Relationship between plasma concentration of sublingual apomorphine and motor score in Parkinson's disease. Eur $\mathcal{f}$ Clin Pharmacol 1991;41:493-94.

12 Montastruc JL, Rascol O, Senard JM, et al. Sublingual apomorphine in Parkinson's disease: a clinical and pharmacokinetic study. Clin Neuropharmacol 1991; 14:432-37

13 Cotzias GC, Papavasiliou PS, Tolosa ES, Mendez JS, BellMidura MM. Treatment of Parkinson's disease with aporphine. N Engl f Med 1976;294:567-72.

14 Kleedorfer B, Turjanski N, Ryan R, Lees AJ, Milroy C, Stern GM. Intranasal apomorphine in Parkinson's disease. Neurology 1991;41:761-2.

\section{Lucja Frey and the "Auriculo-temporal syn- drome"}

Frey's syndrome' - reflex salivation with sweating and flushing over half of the face-is commonly the result of damage to the peripheral facial nerve by parotitis, surgery or trauma. The abnormal sweating is provoked by strong tastes and spices. Rarely, it appears spontaneously without evident pathology. ${ }^{2}$

Burton and Brochwicz-Lewinski have recently shed light on Lucja Frey and her work. ${ }^{3}$ Born in Lwow, Eastern Poland, she graduated in philosophy and mathematics before reading medicine at Lwow University. She later became senior assistant in neurology at Warsaw (1921-28) with Professor Kazimierz Orzechowski. Described as: "modest, quiet, and as hardworking as an ant, she was distinguished to no mean extent by innovative creativity ....".

In addition to her description of gustatory sweating she published several papers in Polish, with works on brain topography, the anatomical changes in Charcot joints, and a case of aneurysm of the plexus of the medulla.
She died at the hands of the Nazis in 1943.

Though known as Frey's syndrome, earlier descriptions were written by Lipsztat "A case of localised sweating while eating in 1922" (no further reference available). ${ }^{4}$ But the earliest account may be that of Dupheniz in 1757 in a paper on fistulas of Stenson's duct. 5

\section{JMS PEARCE}

1 Frey L. Le syndrome du nerf auriculo-temporal. Revue Neurologique 1923;40:97-104.

2 Pearce JMS. Abnormal facial sweating. British $f$ Clinical Practice 1964;18:409-12.

3 Burton MJ, Brochwicz-Lewinski M. Lucja Frey and the auriculotemporal nerve syndrome. f Roy Soc Med 1991;84:619-20.

4 Herman EJ. Historia Neurologii Polshkiej. Wroclaw: Zaklad Narodowy Imienia Ossoliskich Wydawnicto Polskiej Akademii Nauk, 1975:189-90.

5 Duphenix M. Observations sur les fistules du canal salivaire de Stenson. Memoires de l'Academie Royale de Chirugie 